\title{
Research on the Development of Talents in Rural Areas under the Background of Rural Revitalization-A Case Study of YongNing Township of WanYuan City
}

\author{
Chunyan Zhou' ${ }^{1}$, Yuyin $\mathrm{Li}^{2}$ \\ ${ }^{1}$ Personnel Department, Sichuan University of Arts and Science, Dazhou, China \\ ${ }^{2}$ College of Innovation and Entrepreneurship, Sichuan University of Arts and Science, Dazhou, China \\ Email: 158263540@qq.com
}

How to cite this paper: Zhou, C.Y. and Li, Y.Y. (2018) Research on the Development of Talents in Rural Areas under the Background of Rural Revitalization-A Case Study of YongNing Township of WanYuan City. Open Journal of Social Sciences, 6, 251-257.

https://doi.org/10.4236/jss.2018.612022

Received: November 20, 2018

Accepted: December 26, 2018

Published: December 29, 2018

Copyright $\odot 2018$ by authors and Scientific Research Publishing Inc. This work is licensed under the Creative Commons Attribution International License (CC BY 4.0).

http://creativecommons.org/licenses/by/4.0/

\begin{abstract}
The development of Talent is the base of rural prosperity. YongNing township of WanYuan City, a national poverty county, is chosen for this research. Through the interview with village cadres, villagers and some leading local authorities, the author realizes its problem in the development of talents, and puts forward some solutions to help local government to introduce and retain talents in order to realize rural revitalization.
\end{abstract}

\section{Keywords}

Rural Revitalization, Development of Talents, Measure

\section{Introduction}

In accordance with spirit of $19^{\text {th }}$ National Congress of the Communist Party of China and the four comprehensive strategic deployments of central committee, Dazhou municipal party committee and government issued the rural revitalization strategy and planning consulting report of Dazhou of 2018, which gave more comprehensive arrangements for the rural revitalization of Dazhou. 2018, Dazhou puts the following three things as priorities, namely, precaution of major risks, alleviation of poverty, and pollution prevention, which are called as "three big battles". Alleviation of poverty, as one of the "three big battles", will be to develop into "A battle year of poverty", which focuses on the "four poor provinces, 319 poor countries, 150,700 poor people out of poverty". In order to achieve this goal, local authorities need make adequate preparation. The key to 
running rural affairs well and revitalizing rural areas lies in upholding and improving the party's leadership in the work related to agriculture, rural areas and farmers. It is the guarantee for the revitalization of rural areas in management to build thousands of strong grass-roots party organizations in rural areas and train thousands of outstanding leaders of grass-roots party organizations in rural areas [1]. Selecting and sending a large number of outstanding cadres to villages in Dazhou are the basic need for the implementation of the strategy of rural revitalization in Dazhou. This investigation reveals that the shortage of talents in Yongning township is the main problem, less than 30 township clerks with college or technical secondary school education, and almost no workers in village with university education. Therefore, under the current situation of Yongning township, Wanyuan city, the following measures are put forward in order to achieve the revitalization of rural areas.

\section{Rural Grass-Roots Organization: Self-Development and Enhance of Its Own Advantages}

Countryside is the key of rural revitalization. To achieve rural revitalization, countryside should not sole rely on the support of the central government and society, and they should mainly depend on themselves, that is to say, they must find their own ways to alleviate poverty and become prosperity. Rural grassroots should actively improve their own conditions, change people's previous prejudice against the "poor, dirty" rural areas, build a good platform to attract talents outside. In the era of rapid economic development, countryside should seize this opportunity to ride on the express train of "Alleviation of poverty by the state". Relying on their own strength and with the support of national policies, countryside should remove the label of "poverty" forever, uprooted the root of "poverty" and embarked on the road to wealth.

\subsection{Improving Infrastructure}

Road network is the key for countryside to get on the way of prosperity, as the saying goes: "build road to be rich". Cement roads and improved traffic conditions is the line separating countryside from the outside. By firmly relying on this line, rural villagers will have the opportunity to walk out of the mountains and the outside world will have the opportunity to understand the countryside. Now is the information age, without network and communication will be isolated. The new era and the new countryside is based on network. Medical treatment, education and other important infrastructure must also be improved to meet the needs of villagers. Four village communities in Yongning township are with basic road network, which can be accessed by every villagers. Every village community has actively installed network communication facilities, and the village network has basically reached "household access". Due to its mountainous location, the terrain fluctuates greatly, and most mountainous areas still lack network signals. In terms of medical infrastructure, there is a clinic in each 
equipped with a doctor and necessary medical equipment and drugs. Although they are far from perfect, they are constantly on the way of improvement. This is not only convenient for residents in the village, but also adds advantages to the local government to attraction of talents outside.

\subsection{Carry out Technical Training to Improve the Quality of Farmer}

At present, there are night schools, library and other cultural infrastructure construction for peasants in countryside, which can be effectively utilized by villagers. The most important thing for countryside is to develop planting and breeding industry, therefore, what countryside and peasants need most is talents with planting and breeding technology. Only with know these technologies, they will not be helpless in the face of crop diseases and insect pests. In this investigation, peasants of Lingzi village planted kiwi, with the hope of harvest, However, kiwi is infected with canker disease, while peasants could find any method to deal with. Consequently, they suffer great lost this year. Suppose if there is a very professional expert in this field, perhaps all the problems have been solved. Local authorities can use the night school of peasant, or invite local experts and technicians in a certain field to instruct the relevant knowledge and skills training. They can also put books about the latest planting and breeding technologies in the local library to encourage peasant to learn relevant knowledge in order to improve themselves. Then that the local library can really play a great role rather than a waste of resources.

\subsection{Changing Thoughts and Keeping Up with the Times}

Farmers are the main body of the countryside, and their thoughts have an important influence on the direction of rural development. What farmers think in their hearts is what they will do. But in today's era with advanced science and technology and information technology, farmers should keep pace with the times, abandon the traditional feudal superstitions of the past, open their hearts and accept new and scientific ideas. Furthermore, they should actively learn scientific and cultural knowledge, enhance their knowledge literacy and enrich their thinking. For the emerging industries in the countryside, they should take an inclusive attitude, voluntarily learn new planting techniques, arm themselves with new scientific ideas, and make themselves new peasants in the new era and new countryside. For example, establish rural e-commerce platform, agricultural products sales and circulation brokers or agents, tourism agricultural development personnel.

\section{Urban and Rural Government Plays an Integrated Leading Role to Make the Enabling and Retaining Environment for Talent by Clever Plans and Outstanding Schemes}

Nowadays, the loss of labor force has been the most serious problem in rural areas. Many villages have become "the hollow villages". Whereas Rural Revitali- 
zation cannot success, even the village will cease to exist without the people in it. Comparably, the urban government has more material and financial resources. Consequently it should use these resources into the rural construction effectively. And in order to attract more and more talents to return to the land and construct and revitalize the countryside, it should stand on the higher position as on a wider macroscopic perspective to make the better plans and policies which would retain the talents to motivate rural strength and spirits on the basis of "setting up a good stage" made by rural grass-roots. Eventually, this will make Rural Revitalization come true.

\subsection{Appropriately Raise the Wage of Rural Talent}

The wage of rural talent is one of the important elements that if the talent will be attracted. However, their present salary is bad. For example, the rural cadres labor and toil with mind and body thus hold up their field work every day, only get a subsidy little more than 1000 yuan every month. Nevertheless, everyone has to support his family by appropriately raise the wage to maintain the normal living expenses at least. The rural talent should be paid a living guarantee that makes him work contentedly and diligently. According to the measures brought forward by Wang Yongchao, the Secretary of Yongning Township Party committee, the talent also can join into the village leading group and have rights in a certain degree as a village cadre.

\subsection{Building Platform for Talent to Make a Career and Innovate}

While developing industries in rural areas, the key is attaining the governmental support. The village has to has some advantages itself to draw the alien talent come to make some Innovation. These advantages could be the good policies, abundant economic support, sound infrastructure, or favorable terms from the banks. The urban government should pay much attention to innovation; provide assistance to the industry on capital and technology. Thus the talent may innovate and build his career contentedly and boldly. While researching in Tiefosi Village and Puziling Village, the writer found the local government paid little attention to the industry development. On that condition, the industry is lack of funds; the farmers are lack of confidence either. For this reason, the government ought to build platform for talent's innovation and make a good entrepreneurial environment.

\subsection{Attaching Great Importance to the Cultivation of Talents}

Agriculture has become updated as agricultural mechanization, system of manufacturing technology-science, industrialized agriculture, IT application to agriculture, etc. in this modern world. Besides, improving the quality of laborers is the deciding factor to realize the above goals. With this understanding, a new group which is called "New Occupational Farmers" has been hastened by the modernization of agriculture. In addition to the general requirement, new professional farmers must meet three other requirements. First, they are the main 
body of free market; Second, they should have high degree of stability, and operate agriculture as a career; Third, they have a high sense of social responsibility and modern concepts [2]. This requires the government to establish training bases for rural talent which cultivates the farmers on modern mechanical manipulation, technology, and practical ability. On the other side, it pays attention to the scholastic general education, improving the teaching quality, and All-around development of moral, intellectual, physical, aesthetics and labor education of rural students whom can be helped to go into the universities and get further study. Finally it will prepare the talent Foundation for Rural Revitalization and continuance development.

\subsection{Set Up a Platform to Introduce Outstanding Cadres and Talents}

Rural revitalization is an upgraded version of targeted poverty alleviation. Among the five major revitalization programs, organizational revitalization is the key, and grass-roots cadres are the core elements, however, there are insufficient rural village cadres. in order to solve this problem, the platform to let those who believe in the countryside can be a place to show themselves should be established, which can attract graduate students, retired veteran cadres, teachers, flow of party members, retired soldiers and other workers to go to village. At the same time, the grass-roots party organization should be enhanced to attract outstanding young farmers. The leading and guiding role of party cadre at the grass-roots level must be given full attention. With the cohesion of the party organization, the guidance of party members and cadres, and the close follow of the peasants, Rural revitalization can be carried out steadily [3]. Only in this way can the grass-root party organization can be built better and stronger so that farmer can be rich, countryside be beautiful and agriculture be stronger, then the countryside can be revitalized comprehensively. And just like the slogan of this place: whether the farmer is rich or not depends on the branch.

\section{Society: Joint Participation and Commitment to Rural Revitalization}

The strategy of Rural Revitalization is a strategy of epochal significance, which needs the joint endeavor of the countryside, the state and the society. As far as talent revitalization is concerned, it is uncertain to rely solely on the existing people in the countryside to realize rural revitalization. Rural revitalization needs many talents who understand rural agriculture, management, market, technology and economy. This requires universities, enterprises, public welfare organizations and other social forces to offer a helping hand, cultivate more excellent talents for rural revitalization, and give more practical talents to rural areas.

\subsection{Practice of College Graduates in Party's Primary Organization}

In 2016, there were more than 7.56 million college graduates in China. In 2017, 
the number was 7.95 million and in 2018, it reached 8.2 million. According to the data, the number of college graduates in China is increasing year by year, and the employment pressure is becoming increasingly tense. Nowadays, the Rural Revitalization is just in the need of talents. College graduates have learned relevant professional knowledge in school. They have a high level of education and have diplomas and academic qualifications. They are the best candidates to help the rural revitalization, especially the graduates of vocational and technical majors. The government and universities should actively guide and encourage college graduates to work in Party's Primary Organization. Rural areas need a team that understands economy, agriculture, market and technology. This is the basis and prerequisite for rural areas to achieve follow-up goals. To some extent, the participation of university graduates in the construction of rural areas not only helps to realize rural development, but also alleviates the pressure of social employment.

\subsection{Scientific Research Institutions Provide Talents Who Are Urgently Needed in Rural Areas}

Scientific research institutes carry out scientific and technological research, possess advanced science and technology and excellent talents. Their offering of urgently needed talents can greatly improve the level of rural production, and to some extent alleviate the current situation of the lack of rural talents. The talents urgently needed in rural areas are mainly technical talents, managerial talents and economic talents. Scientific research institutions can provide a group of high-quality fresh troops for rural areas, apply talents and technology to the core, solve the enormous problems which the rural areas are facing, and provide strong support for the rejuvenation of rural talents.

\subsection{Funds Sponsored by Corporate}

In order to realize rural revitalization, funds are indispensable. They are needed for the construction of infrastructure such as medical, education, transportation. Funds are also needed for better treatment of talents, and governments' subsidies to industries. Enterprises can set up a "rural talent training fund" to provide part of the funds for the revitalization of rural talent with the funds gathered, establish a positive incentive mechanism in the countryside, grant some subsidies to the returnees, and subsidize the innovative and entrepreneurship talents, and reward them after they have achieved remarkable results.

\section{Conclusion}

In brief, rural rejuvenation is the rejuvenation of rural talents. The most important thing for the rejuvenation of rural talents is the talents. Although the author just investigates a poverty-stricken township, which cannot tell all the story, countryside lack of talents is an indisputable fact. Where did the talent come from? One is the existing talents in rural areas, and the other is the introduction 
of talents from other places. Attracting people is the primary thing, and the key is to retain talents. Facing the current situation in the countryside, retaining talents is a problem worth pondering. The revitalization of rural talents is an essential task, which may be difficult to achieve in a short time. Based on the current situation in the countryside, the Party's Primary Organization may have more than one mind and less ability to introduce and retain talents. In order to realize the rejuvenation of rural talents, the state must take measures to achieve population balance between the rural and the urban. Sufficient labor force is needed to achieve development in rural areas. Secondly, a saying goes like this, "building nests to attract Phoenix habitats, blossom flowers attracting butterflies"; rural areas should also focus on their own development and break the shackles. Rural Revitalization is not only a matter of rural areas; it requires the participation of rural, national government and society, coordinated governance, and joint efforts.

\section{Conflicts of Interest}

The authors declare no conflicts of interest regarding the publication of this paper.

\section{References}

[1] Building Tens of Millions of Strong Rural Grass-Roots Party Organizations. 5th Edition, Shanxi Daily, 2018-04-13.

[2] He, W.H. (2016) Differentiation of Farmer Groups and Cultivation of New Professional Farmers in the Process of Agricultural Modernization. Xinjiang Agricultural Reclamation Economy, No. 5, 20-21.

[3] Gu, S.G. (2018) The Grass-Roots Cadres' Role in Rural Revitalization. People's Forum Network, 2018-01-02. 